\title{
Comparative Reproductive Performance and Early Lactation Productivity of Jersey $\times$ Holstein Cows in Predominantly Holstein Herds in a Pasture-Based Dairying System
}

\author{
M. J. Auldist, ${ }^{* 1}$ M. F. S. Pyman, $\dagger$ C. Grainger, ${ }^{*}$ and K. L. Macmillan† \\ *Department of Primary Industries, Ellinbank, Victoria, Australia \\ †Department of Veterinary Science, University of Melbourne, Werribee, Victoria, Australia
}

\section{ABSTRACT}

The aim of this study was to compare the reproductive performance, milk production, live weight, and body condition loss during early lactation of purebred Holstein $(\mathrm{H})$ cows to Jersey $\times \mathrm{H}(\mathrm{J} \times \mathrm{H})$ crossbred cows in 4 Victorian herds. Cows of $\mathrm{H}$ and $\mathrm{J} \times \mathrm{H}$ breeding were managed together within each herd, and all herds had a seasonally concentrated calving pattern that commenced in early spring (July). All crossbred cows included in the study were 25,50 , or $75 \% \mathrm{H}$ and were considered collectively as $\mathrm{J} \times \mathrm{H}$ regardless of the sire and dam breeds used to reach those percentages. Each herd owner provided records of reproductive performance and milk production. Compared with $\mathrm{H}$ cows, $\mathrm{J} \times \mathrm{H}$ cows had higher first-service conception rates (52 vs. $42 \%$ ), higher percentages confirmed pregnant by 6 ( 68 vs. $54 \%$ ) and $14 \mathrm{wk}$ ( $86 \mathrm{vs.} .78 \%$ ) after the first day of inseminating, and lower final not-in-calf rates (11 vs. 16\%); however, these differences were not observed in all herds. A random selection of $\mathrm{H}$ and $\mathrm{J} \times$ $\mathrm{H}$ cows had body condition assessed on 3 occasions between the start of calving and the first day of the artificial insemination program. The selected cows were also weighed on the final occasion. Overall, body condition scores were slightly higher for $\mathrm{J} \times \mathrm{H}$ cows than for $\mathrm{H}$ cows, but changes in body condition score between calving and the start of inseminating were similar between breed groups. The $\mathrm{H}$ cows were $40 \mathrm{~kg}$ heavier than $\mathrm{J} \times \mathrm{H}$ cows and had daily milk yields in early lactation that were $2.2 \mathrm{~kg}$ higher. Daily yields of milk fat and protein did not differ between $\mathrm{H}$ and $\mathrm{J} \times \mathrm{H}$ cows during the study period. The improved reproductive performance of $\mathrm{J} \times \mathrm{H}$ cows compared with $\mathrm{H}$ cows may render them more suitable for use in dairy herds with seasonally concentrated calving patterns. Their improved reproductive performance was not as-

Received December 21, 2006.

Accepted May 24, 2007.

${ }^{1}$ Corresponding author: vfmeditor@fishingmonthly.com.au sociated with differences in condition loss in early lactation.

Key words: cross-bred cow, Jersey, Holstein, reproduction, body condition

\section{INTRODUCTION}

The declining reproductive performance of dairy cattle in many countries has been associated with an increased proportion of genes derived from Holstein (H) sires of North American origin (Butler, 1998; Buckley et al., 2003; Dillon et al., 2003). First-service conception rates in American herds have declined from approximately 65\% in 1951 to $40 \%$ in 1996 (Lucy, 2001) with equivalent decreases in the United Kingdom (Pryce and Veerkamp, 2001) and Ireland (Dillon et al., 2003). The decline in reproductive performance of $\mathrm{H}$ cows grazing pasture has been associated with large weight losses in early lactation when cows mobilize body adipose reserves to achieve high milk yields (Beever et al., 2001; Fulkerson et al., 2001; Snijders et al., 2001).

Low reproductive performance in a seasonally concentrated calving system is exacerbated by insufficient time to recover from the negative energy balance of early lactation because the required time of breeding coincides with peak lactation (Borman et al., 2004). As a consequence, herd owners can have difficulty maintaining the 12-mo calving interval essential to seasonally concentrated calving. There is evidence this has occurred in Victoria: from 2004 to 2006 the proportion of seasonally calving herds in Victoria declined from 63 to 41\% (Dairy Australia, 2006). Additionally, the InCalf Project, a large Australian study that measured the reproductive performance of cows in 124 herds with seasonally concentrated calving patterns (Morton, 1999), documented that the proportion of cows pregnant in the first 6 wk of the AI program was only $63 \%$ (Morton, 1999). Ideally, it would be $75 \%$ to maintain a concentrated calving pattern in a seasonal calving system. These figures suggest many Australian herd owners are also struggling to maintain satis- 
factory reproductive performance in their herds. At the same time, there has been a strong shift to using semen from $\mathrm{H}$ sires of North American origin within the Australian dairy cow population as indicated by the proportion of the $\mathrm{H}$ breed in recorded herds increasing from $40 \%$ in 1978 to more than $80 \%$ in 2002 (Carrick, 2003).

A recent study suggested that one way to improve the reproductive performance of cows in Victorian herds was to breed Jersey $\times \mathrm{H}(\mathbf{J} \times \mathbf{H})$ crossbred cattle instead of purebred H cattle (White, 2001). Similarly, a New Zealand study demonstrated that $\mathrm{H}$ cows had a significantly lower survival in seasonally calving herds than $\mathrm{J} \times \mathrm{H}$ crossbred cows because of their lower fertility (Lopez-Villalobos et al., 2000). This suggests that $\mathrm{J} \times \mathrm{H}$ crossbred cattle may be more suitable than pure $\mathrm{H}$ cows for use by herd owners who choose to maintain a seasonally concentrated calving pattern to maximize the use of pasture as an economical feed source.

The present experiment had the aim of quantifying the differences in reproductive performance between $\mathrm{H}$ and $\mathrm{J} \times \mathrm{H}$ cattle in 4 commercial herds in Victoria. Data were also collected to test the hypothesis that differences in losses of BCS and BW in H cows compared with $\mathrm{J} \times \mathrm{H}$ cows were negatively related to reproductive performance.

\section{MATERIALS AND METHODS}

\section{Herds}

The 4 selected herds were in Gippsland, 2 from within the Macalister irrigation district near Maffra (latitude $37^{\circ} 58^{\prime} 37^{\prime \prime}$, longitude $146^{\circ} 58^{\prime} 37^{\prime \prime}$; herds A and B), and 2 were rain-fed farms from near Warragul (latitude $38^{\circ} 14^{\prime} 36^{\prime \prime}$, longitude $145^{\circ} 56^{\prime} 10^{\prime \prime}$; herds $\mathrm{C}$ and D). Each farm included $\mathrm{H}$ and $\mathrm{J} \times \mathrm{H}$ cows under common management conditions and participated in a herd-testing program. In 2003, herd A was visited on September 4, October 13, and November 12; herd B on September 5, October 14, and November 14; herd $\mathrm{C}$ on August 21, September 17, and October 24; and herd D on July 25, August 29, and October 6.

\section{Cows}

The 4 herds were stratified into $\mathrm{H}$ and $\mathrm{J} \times \mathrm{H}$ cows based on their herd breeding records. Cows that had an unknown sire or dam in their breeding records were excluded from the data set unless the herd owner was able to provide evidence of three generations of ancestry. To be included as a crossbred $\mathrm{J} \times \mathrm{H}$ cow, cows had to be recorded as being $25 \% \mathrm{~J}$ and $75 \% \mathrm{H}$ (HHHJ or HHJH), $50 \% \mathrm{~J}$ and $50 \% \mathrm{H}$ (JJHH or HHJJ), or $75 \% \mathrm{~J}$ and $25 \% \mathrm{H}$ (JJJH or JJHJ). This recording system is the official system of the Australian Dairy Herd Improvement Service. The first 2 letters relate to the breeding of the sire and the last 2 letters to the breeding of the dam (for example a cow recorded as HHHJ is the progeny of a pure Holstein sire and a crossbred dam). Only these listed combinations (above) occurred in the study herds. Purebred Holstein cows were designated HHHH.

Reproductive data are presented for all cows that met the above criteria. The two herds in the Macalister irrigation region were too large to weigh every cow (i.e., $>400$ cows) without compromising the time the herd spent at pasture. In these herds, approximately 100 cows were randomly selected for study (approximately 50 of each breed, balanced for age as closely as possible). In the remaining 2 herds, every cow was weighed. For all measurements except reproductive variables, data are presented only for cows that were weighed, were present and identifiable on at least 2 visits, and were enrolled for at least one herd test during the study period (for example, at an early visit some cows in a herd were yet to calve; at other times, some cows were not in the main herd).

The number of cows studied in each breed category for measurements other than reproductive variables is presented in Table 1, along with an estimate of the proportions of $\mathrm{H}$ genetics amongst the studied cows (calculated by averaging the percentage Holstein for each individual cow in each group). Mean cow age and the spread of calving dates are also presented for the studied cows in each herd.

\section{Measurements}

Reproductive Variables. Each herd owner maintained complete breeding records on a herd management software program. The cows were pregnancy tested at least 6 wk after the seasonal AI program was completed, and those that were not pregnant were retested 6 wk after the end of the natural service breeding period.

The records for each herd were collected and downloaded into the herd management program, DairyData for Windows (Warnnambool Animal Production Services, Warrnambool Victoria, Australia) and the reproductive performance indices for the $\mathrm{H}$ and $\mathrm{J} \times \mathrm{H}$ cows in each herd calculated. The indices generated by the program included 21-d submission rate (21dSR; proportion of herd that was artificially inseminated in the first $21 \mathrm{~d}$ of the seasonally concentrated artificial insemination program); conception rate to first insemination (first CR); 6 wk in-calf rate (6wICR; proportion of cows pregnant in the first $6 \mathrm{wk}$ of the AI program); 14 wk in-calf rate (14-wICR; pro- 
Table 1. Mean proportions of Holstein $(\mathrm{H})$ genetics, numbers of cows, mean ages, and calving windows for the groups of $\mathrm{H}$ and Jersey $\times \mathrm{H}$ cows $(\mathrm{J} \times \mathrm{H})$ studied in 4 herds (for variables other than reproductive indices)

\begin{tabular}{|c|c|c|c|c|c|}
\hline Herd & Breed & $\begin{array}{c}\text { Mean } \\
\% \mathrm{H}\end{array}$ & $\begin{array}{l}\text { Number } \\
\text { of cows }\end{array}$ & $\begin{array}{l}\text { Mean } \\
\text { age (yr) }\end{array}$ & Calving window \\
\hline \multirow[t]{2}{*}{$\mathrm{A}$} & $\mathrm{H}$ & 100 & 46 & 4.6 & July 25 to September 1 \\
\hline & $\mathrm{J} \times \mathrm{H}$ & 57 & 46 & 4.5 & July 24 to August 8 \\
\hline \multirow[t]{2}{*}{ B } & $\mathrm{H}$ & 100 & 47 & 3.2 & July 29 to September 30 \\
\hline & $\mathrm{J} \times \mathrm{H}$ & 51 & 48 & 3.2 & July 26 to October 9 \\
\hline \multirow[t]{2}{*}{$\mathrm{C}$} & $\mathrm{H}$ & 100 & 52 & 4.9 & July 31 to August 23 \\
\hline & $\mathrm{J} \times \mathrm{H}$ & 43 & 11 & 5.4 & July 28 to August 22 \\
\hline \multirow[t]{2}{*}{$\mathrm{D}$} & $\mathrm{H}$ & 100 & 107 & 4.7 & June 20 to September 25 \\
\hline & $\mathrm{J} \times \mathrm{H}$ & 56 & 21 & 5.3 & July 23 to September 25 \\
\hline
\end{tabular}

portion of cows pregnant in the first $14 \mathrm{wk}$ of the AI program); and not in-calf rate (NIC).

The 6-wICR, 14-wICR, and NIC figures are considered to be primary indicators of reproductive performance in seasonally calving herds (Morton, 1999), whereas 21-dSR is an indicator of concentration of breeding (Macmillan and Watson, 1975).

Milk Production and Composition. Daily milk yield and concentrations of fat and protein were routinely measured as part of each herd's normal production recording program. Milk samples were analyzed using an infrared milk analyzer. These measurements were used to determine yields of milk components.

During the study period (between the start of the calving program and the start of the AI program) each herd had 1 (herds A and B) or 2 official samplings (herds $\mathrm{C}$ and $\mathrm{D}$ ). Where 2 herd tests occurred, data presented are mean values for the 2 tests.

$\boldsymbol{B C S}$ and $\boldsymbol{B W}$. Every enrolled cow had BCS assessed on 3 occasions at approximately monthly intervals between calving and the start of the herd's AI program. The scoring was done by the same 3 trained assessors using an 8-point scale (Earle 1976; Roche et al., 2004). At the final BCS visit (the visit closest to the start of AI), the enrolled cows were weighed using a set of portable scales.

Statistical Analyses. Odds ratios were calculated for the reproductive indices using logistic regression (Hosmer and Lemeshow, 2000) and the statistical analysis program GenStat (2006). This was done for each herd and for the data set as a whole with the linear predictor including the fixed main effects of herd and breed. For the combined data, predictions for breed were formed on the logit scale, averaging over farm effects, and back-transformed to percentages.

For variables other than reproductive performance, GenStat was used to conduct ANOVA and calculate least significant differences for each variable each time it was measured in each herd. A blocking factor for herd was included when analyzing the combined data.
Residuals were checked graphically for normality of distribution and homogenous variance.

\section{RESULTS}

\section{Reproductive Performance}

Measures of reproductive performance (21-dSR, first CR, 6-wICR, 14-wICR, NIC) for cows in the 4 study herds are presented in Table 2. Data are fitted (adjusted) values from the described logistic model (though in practice the adjusted values were almost identical to the raw observed values). In the data combined across herds, $\mathrm{J} \times \mathrm{H}$ cows had a higher first $\mathrm{CR}$, higher 6 -wICR and 14 -wICR, and lower NIC rates $(P<$ $0.05)$ than $\mathrm{H}$ cows, but 21 -dSR did not differ $(P=0.11)$.

\section{$B C S$ and $B W$}

Cow BCS at 3 visits and BW at the final visit are presented for the enrolled cows in each herd in Table 3. Data for individual herds were identical to the observed raw means, but data presented for the combined data are adjusted values from the statistical model. There were no differences in the mean BCS of $\mathrm{H}$ and $\mathrm{J} \times \mathrm{H}$ cows at any of the 3 visits for 3 of the study herds (Table 3 ). At all 3 visits to herd $\mathrm{C}$, the $\mathrm{J}$ $\times \mathrm{H}$ cows had a higher $(P<0.001)$ average BCS than $\mathrm{H}$ cows. In the combined data, BCS was higher $(P<$ 0.05 ) for $\mathrm{J} \times \mathrm{H}$ cows than $\mathrm{H}$ cows at all 3 visits.

There was no difference in the BCS change between visit 1 and visit 3 for $\mathrm{H}$ and $\mathrm{J} \times \mathrm{H}$ cows in any of the herds, or for the combined data (Table 3). Change in BCS was always numerically negative (Table 3 ), but losses were small (for the 4 herds the average changes were -0.18 and -0.21 of a BCS for $\mathrm{H}$ and $\mathrm{J} \times \mathrm{H}$ cows, respectively). Consequently, calculated BW loss was also small in most instances (the combined data showed losses of less than $1.8 \%$ of $\mathrm{BW}$ for $\mathrm{H}$ and $\mathrm{J} \times$ $\mathrm{H}$ cows). In herd $\mathrm{D}$, however, $\mathrm{H}$ cows lost 0.41 of a BCS, whereas $\mathrm{J} \times \mathrm{H}$ cows lost 0.49 of a BCS. In that 
Table 2. Twenty-one day submission rates (21-dSR, \%), conception rates after first insemination (first CR, $\%)$, proportion of cows pregnant in the first $6 \mathrm{wk}(6-\mathrm{wICR}, \%)$ and $14 \mathrm{wk}$ (14-wICR, \%) of the seasonally concentrated AI program, and not-in-calf rates (NIC, \%) for Holstein $(\mathrm{H})$ and Jersey $\times \mathrm{H}(\mathrm{J} \times \mathrm{H})$ cows $^{1}$

\begin{tabular}{|c|c|c|c|c|c|c|c|}
\hline Herd & Breed & No. of cows ${ }^{2}$ & 21-DSR & First CR & 6-wICR & 14-wICR & NIC \\
\hline \multirow[t]{4}{*}{ A } & $\mathrm{H}$ & 290 (287) & 94 & 48 & 64 & 87 & 7 \\
\hline & $\mathrm{J} \times \mathrm{H}$ & 119 (117) & 94 & 55 & 74 & 88 & 8 \\
\hline & Odds ratio & - & 1.00 & 1.32 & 1.61 & 1.17 & 1.18 \\
\hline & $P$-value & - & 0.99 & 0.20 & 0.05 & 0.64 & 0.69 \\
\hline \multirow[t]{4}{*}{ B } & $\mathrm{H}$ & 402 (333) & 74 & 37 & 46 & 70 & 20 \\
\hline & $\mathrm{J} \times \mathrm{H}$ & 131 & 80 & 52 & 61 & 85 & 11 \\
\hline & Odds ratio & - & 1.45 & 1.86 & 1.82 & 2.33 & 0.48 \\
\hline & $P$-value & - & 0.13 & 0.004 & 0.003 & 0.001 & 0.020 \\
\hline \multirow[t]{4}{*}{$\mathrm{C}$} & $\mathrm{H}$ & 146 (129) & 80 & 41 & 51 & 79 & 21 \\
\hline & $\mathrm{J} \times \mathrm{H}$ & $46(42)$ & 89 & 45 & 76 & 87 & 13 \\
\hline & Odds ratio & - & 2.03 & 1.18 & 3.10 & 1.80 & 0.58 \\
\hline & $P$-value & - & 0.17 & 0.64 & 0.003 & 0.22 & 0.26 \\
\hline \multirow[t]{4}{*}{ D } & $\mathrm{H}$ & 121 (108) & 73 & 44 & 61 & 79 & 22 \\
\hline & $\mathrm{J} \times \mathrm{H}$ & $27(22)$ & 70 & 55 & 67 & 82 & 19 \\
\hline & Odds ratio & - & 0.89 & 1.56 & 1.27 & 1.20 & 0.83 \\
\hline & $P$-value & - & 0.42 & 0.35 & 0.59 & 0.76 & 0.73 \\
\hline \multirow[t]{4}{*}{ Combined } & $\mathrm{H}$ & 959 (857) & 81 & 42 & 54 & 78 & 16 \\
\hline & $\mathrm{J} \times \mathrm{H}$ & $323(296)$ & 85 & 52 & 68 & 86 & 11 \\
\hline & Odds ratio ${ }^{3}$ & - & 1.34 & 1.51 & 1.83 & 1.74 & 0.66 \\
\hline & $P$-value & - & 0.11 & 0.003 & 0.001 & 0.002 & 0.031 \\
\hline
\end{tabular}

${ }^{1}$ Data are fitted values from the logistic model but are almost identical to the raw observed means.

${ }^{2}$ Numbers in parentheses are number of cows receiving a first insemination.

${ }^{3}$ Adjusted for herd effect.

herd, this translated into calculated BW losses of 16.3 and $18.5 \mathrm{~kg}$ for $\mathrm{H}$ and $\mathrm{J} \times \mathrm{H}$ cows between calving and mating.

In 2 herds, $\mathrm{H}$ cows were heavier $(P<0.001)$ than $\mathrm{J}$ $\times \mathrm{H}$ cows (Table 4 ), by $42 \mathrm{~kg}$ (herd A) and $63 \mathrm{~kg}$ (herd B). In the other 2 herds, BW of $\mathrm{H}$ and $\mathrm{J} \times \mathrm{H}$ cows did not differ statistically. Overall, the average difference in $\mathrm{BW}$ between $\mathrm{H}$ and $\mathrm{J} \times \mathrm{H}$ cows was $+40 \mathrm{~kg}$ (adjusted mean for all cows studied).

\section{Milk Yield and Composition}

The yield of milk produced per cow was greater $(P$ $<0.05$ ) for pure $\mathrm{H}$ cows compared with crossbred $\mathrm{J} \times$ $\mathrm{H}$ cows in herds $\mathrm{A}$ and $\mathrm{B}$, and in the combined data (Table 4). Concentrations of fat and protein in milk from $\mathrm{J} \times \mathrm{H}$ cows were always greater $(P<0.001)$ than for $\mathrm{H}$ cows. Daily yields of protein per cow were greater for $\mathrm{H}$ cows than $\mathrm{J} \times \mathrm{H}$ cows in herd $\mathrm{B}$, but not in the combined data. Daily yields of fat per cow were greater $(P<0.01)$ for $\mathrm{J} \times \mathrm{H}$ cows than for $\mathrm{H}$ cows in herd $\mathrm{D}$, but there was no difference overall.

\section{DISCUSSION}

The current experiment showed a definitive advantage of $\mathrm{J} \times \mathrm{H}$ cows over $\mathrm{H}$ cows in terms of their reproductive performance in a seasonally calving, pasturebased dairying system. The enhanced first-CR, 6-
wICR, 14-wICR, and reduced NIC rates in $\mathrm{J} \times \mathrm{H}$ cows compared with $\mathrm{H}$ cows should mean that these $\mathrm{J} \times \mathrm{H}$ cows would be better able to fulfill the requirements for maintaining a seasonally concentrated calving pattern. These results were in agreement with a previous Victorian study (White, 2001) that also showed superior conception and pregnancy rates of $\mathrm{J} \times \mathrm{H}$ cows compared with $\mathrm{H}$ cows as measured by increased 6wICR and 21-wICR. That study, however, did not investigate $\mathrm{BW}$, BCS, or DMI.

The link between high production and poor reproduction of dairy cows is well recognized in American studies (Lucy, 2001). Furthermore, H cows offered TMR and producing over 10,000 L/lactation in the United Kingdom and America have recorded losses in body fat of up to $100 \mathrm{~kg}$ in early lactation (Beever et al., 2001). The current experiment put forward the hypothesis that reputed differences in reproductive performance between $\mathrm{H}$ and $\mathrm{J} \times \mathrm{H}$ cows were associated with $\mathrm{H}$ cows losing more condition in early lactation. Evidence for this hypothesis exists in previous within-breed studies. For example, Snijders et al. (2001) found that dairy cows that had significant BW loss in early lactation, and were consequently in a state of greater negative energy balance, had more reproductive problems than cows that lost less BW. Similarly, in an Australian study, Fulkerson et al. (2001) reported that high genetic merit $\mathrm{H}$ cows on a 
Table 3. Mean BCS at each farm visit, BCS change, and calculated BW loss for Holstein (H) and Jersey $\times$ $\mathrm{H}(\mathrm{J} \times \mathrm{H})$ cows in the 4 study herds ${ }^{1}$

\begin{tabular}{|c|c|c|c|c|c|c|}
\hline \multirow[b]{2}{*}{ Herd } & \multirow[b]{2}{*}{ Breed } & \multicolumn{3}{|c|}{ BCS } & \multirow{2}{*}{$\begin{array}{c}\Delta \mathrm{BCS} \\
1-3\end{array}$} & \multirow{2}{*}{$\begin{array}{c}\mathrm{BW}^{2} \text { lost } \\
\quad(\mathrm{kg})\end{array}$} \\
\hline & & Visit 1 & Visit 2 & Visit 3 & & \\
\hline \multirow[t]{4}{*}{ A } & $\mathrm{H}$ & 4.47 & 4.47 & 4.40 & -0.07 & 2.8 \\
\hline & $\mathrm{J} \times \mathrm{H}$ & 4.51 & 4.50 & 4.45 & -0.06 & 2.2 \\
\hline & LSD & 0.116 & 0.101 & 0.094 & 0.084 & - \\
\hline & $P$-value & 0.571 & 0.523 & 0.286 & 0.679 & - \\
\hline \multirow[t]{4}{*}{ B } & $\mathrm{H}$ & 4.47 & 4.47 & 4.42 & -0.04 & 1.6 \\
\hline & $\mathrm{J} \times \mathrm{H}$ & 4.54 & 4.55 & 4.45 & -0.10 & 3.5 \\
\hline & LSD & 0.103 & 0.120 & 0.087 & 0.103 & - \\
\hline & $P$-value & 0.135 & 0.180 & 0.577 & 0.215 & - \\
\hline \multirow[t]{4}{*}{$\mathrm{C}$} & $\mathrm{H}$ & 4.66 & 4.60 & 4.56 & -0.10 & 3.7 \\
\hline & $\mathrm{J} \times \mathrm{H}$ & 4.94 & 4.89 & 4.89 & -0.04 & 1.5 \\
\hline & LSD & 0.156 & 0.170 & 0.179 & 0.179 & - \\
\hline & $P$-value & $<0.001$ & $<0.001$ & $<0.001$ & 0.499 & - \\
\hline \multirow[t]{4}{*}{ D } & $\mathrm{H}$ & 4.87 & 4.63 & 4.46 & -0.41 & 16.3 \\
\hline & $\mathrm{J} \times \mathrm{H}$ & 4.98 & 4.61 & 4.49 & -0.49 & 18.5 \\
\hline & LSD & 0.166 & 0.124 & 0.104 & 0.167 & - \\
\hline & $P$-value & 0.178 & 0.771 & 0.477 & 0.409 & - \\
\hline \multirow{4}{*}{ Combine } & $\mathrm{H}$ & 4.63 & 4.55 & 4.45 & -0.18 & 7.2 \\
\hline & $\mathrm{J} \times \mathrm{H}$ & 4.73 & 4.61 & 4.52 & -0.21 & 7.6 \\
\hline & LSD & 0.068 & 0.061 & 0.053 & 0.067 & - \\
\hline & $P$-value & 0.005 & 0.030 & 0.007 & 0.508 & - \\
\hline
\end{tabular}

${ }^{1}$ For individual herds, data are identical to the raw observed means, but for overall data means have been adjusted according to the statistical model.

${ }^{2} \mathrm{~A}$ loss of 1 BCS was calculated to represent $0.08 \times$ BW (Standing Committee on Agriculture, 1990).

low concentrate diet had a lowered reproductive performance compared with low genetic merit $\mathrm{H}$ cows, and that this difference was also associated with greater BW loss in early lactation.

The current study has provided no evidence to support the hypothesis that reproductive differences be- tween $\mathrm{H}$ and $\mathrm{J} \times \mathrm{H}$ cows (observed in the study) were due to differences in BCS change during early lactation. No differences in BCS loss between calving and the start of AI were observed between $\mathrm{H}$ and $\mathrm{J} \times \mathrm{H}$ cows in any herd, in spite of the observed differences in reproductive performance in those same herds. The

Table 4. Mean BW, milk yield, and percentage and yields of milk components for Holstein (H) and Jersey $\times \mathrm{H}(\mathrm{J} \times \mathrm{H})$ cross cows in each study herd ${ }^{1}$

\begin{tabular}{llcccccc}
\hline Herd & Breed & $\begin{array}{c}\text { BW } \\
(\mathrm{kg})\end{array}$ & $\begin{array}{c}\text { Milk } \\
(\mathrm{kg} / \mathrm{d})\end{array}$ & $\begin{array}{c}\text { Fat } \\
(\%)\end{array}$ & $\begin{array}{c}\text { Protein } \\
(\%)\end{array}$ & $\begin{array}{c}\text { Fat } \\
(\mathrm{g} / \mathrm{d})\end{array}$ & $\begin{array}{c}\text { Protein } \\
(\mathrm{g} / \mathrm{d})\end{array}$ \\
\hline A & H & 493 & 30.3 & 3.73 & 3.25 & 1125 & 980 \\
& J $\times \mathrm{H}$ & 451 & 27.8 & 3.92 & 3.37 & 1080 & 934 \\
& LSD & 24 & 2.30 & 0.191 & 0.085 & 92 & 72 \\
& $P$-value & $<0.001$ & 0.034 & 0.049 & 0.006 & 0.343 & 0.209 \\
B & H & 502 & 29.3 & 3.56 & 3.14 & 1,033 & 919 \\
& J $\times$ H & 439 & 25.3 & 3.97 & 3.26 & 998 & 822 \\
& LSD & 21 & 2.00 & 0.180 & 0.084 & 71 & 62 \\
& $P$-value & $<0.001$ & $<0.001$ & $<0.001$ & 0.007 & 0.326 & $<0.001$ \\
C & H & 462 & 22.2 & 4.00 & 3.57 & 879 & 787 \\
& J $\times$ H & 456 & 19.2 & 4.46 & 3.86 & 840 & 736 \\
& LSD & 46 & 3.35 & 0.342 & 0.198 & 127 & 119 \\
& $P$-value & 0.768 & 0.085 & 0.012 & 0.005 & 0.548 & 0.394 \\
D & H & 495 & 32.0 & 3.64 & 3.19 & 1163 & 1021 \\
& J $\times$ H & 472 & 33.0 & 4.02 & 3.34 & 1318 & 1102 \\
& LSD & 30 & 2.88 & 0.175 & 0.087 & 115 & 96 \\
& $P$-value & 0.142 & 0.507 & $<0.001$ & $<0.001$ & 0.009 & 0.097 \\
Overall & H & 490 & 29.1 & 3.70 & 3.26 & 1069 & 942 \\
& J $\times$ H & 450 & 26.9 & 4.04 & 3.40 & 1076 & 909 \\
& LSD & 14.0 & 1.27 & 0.100 & 0.050 & 49.6 & 41.6 \\
& $P$-value & $<0.001$ & $<0.001$ & $<0.001$ & $<0.001$ & 0.782 & 0.123 \\
\hline
\end{tabular}

\footnotetext{
${ }^{1} \mathrm{LSD}=$ least significant difference $(P<0.05)$.
} 
higher BCS loss in one herd (herd D) compared with the other herds was probably related to the fact that mean BCS at calving was higher for that herd. Grainger et al. (1982) reported that cows calving at a BCS of 4.5 and consuming $14 \mathrm{~kg}$ of DM pasture per day exhibited little change in BCS over the first 5 wk of lactation. Our results are consistent with this observation: herds A, B, and C calved at a BCS of around 4.5 on an 8-point scale and showed little change during early lactation.

The current study provides an estimate of the differences in $\mathrm{BW}$ of $\mathrm{H}$ and $\mathrm{J} \times \mathrm{H}$ cows occurring in Victorian herds. Overall, the mean difference in BW between $\mathrm{H}$ and $\mathrm{J} \times \mathrm{H}$ cows was $40 \mathrm{~kg}$. This is similar to the reported difference of $42 \mathrm{~kg}$ for $\mathrm{H}$ and $\mathrm{J} \times \mathrm{H}$ dairy cows of a similar average age in the New Zealand national herd (Livestock Improvement Corporation, 2003). The absolute BW for $\mathrm{H}$ and $\mathrm{J} \times \mathrm{H}$ cows in New Zealand were also similar to the overall averages in our study: in the current study $\mathrm{H}$ and $\mathrm{J} \times \mathrm{H}$ cows weighed 490 and $450 \mathrm{~kg}$, whereas those New Zealand cows reported by Livestock Improvement Corporation (2003) weighed 504 and $462 \mathrm{~kg}$.

The $\mathrm{H}$ cows yielded more milk than $\mathrm{J} \times \mathrm{H}$ cows for 3 of the 4 study farms during the study period. A similar difference in milk yield was reported by White (2001), although the magnitude of the difference in that study was slightly smaller and the absolute milk yields lower than for the current study (White reported overall yields of 19.5 vs. $18.1 \mathrm{~kg}$ for $\mathrm{H}$ and $\mathrm{J} \times \mathrm{H}$ cows, respectively, whereas equivalent values in the current study were 29.1 and $26.9 \mathrm{~kg}$ ). Higher concentrations of fat and protein in milk from $\mathrm{J} \times \mathrm{H}$ cows compared with $\mathrm{H}$ cows resulted similar daily yields of fat and protein between breed groups. This is significant to Victorian herd owners, who are paid for milk based on the quantities of fat and protein supplied, with a penalty for milk volume. It is important to note, however, that these observations regarding milk production in early lactation may not be substantiated when considering total lactation production.

This study showed that $\mathrm{J} \times \mathrm{H}$ cows had superior conception rates and pregnancy rates to $\mathrm{H}$ cows. The $\mathrm{J} \times \mathrm{H}$ cows produced less milk in early lactation than $\mathrm{H}$ cows, but had higher concentrations of fat and protein than $\mathrm{H}$ cows. Few significant differences were observed in the total amounts of milk fat and protein produced by $\mathrm{J} \times \mathrm{H}$ and $\mathrm{H}$ cows during the study period. The $\mathrm{J} \times \mathrm{H}$ cows were an average of $40 \mathrm{~kg}$ lighter, but no difference was observed between breeds in terms of BCS loss in early lactation. In conclusion, the results of this study show that $\mathrm{J} \times \mathrm{H}$ cows would have some advantages over $\mathrm{H}$ cows in dairy systems with seasonally concentrated calving patterns where reproductive performance is an especially important factor influencing herd profitability. Economic analyses incorporating full lactation production data needs to be undertaken to determine of these reproductive advantages render $\mathrm{J} \times \mathrm{H}$ cows more suitable for use in such systems.

\section{ACKNOWLEDGMENTS}

This study would not have been possible without the cooperation of the 4 herd owners who provided access to their herds and assisted with the condition scoring and weighing of their cows. Thanks also to D. Mapleson and I. Robinson (DPI Ellinbank) for weighing and condition scoring of cows. Statistical analyses were conducted by G. Anderson (University of Melbourne) and M. Hannah (Department of Primary Industries). This project was funded by the Department of Primary Industries, GippsDairy and the Geoffrey Gardiner Dairy Foundation Ltd.

\section{REFERENCES}

Beever, D. E., A. J. Hattan, S. B. Cammell, and J. D. Sutton. 2001. Nutritional management of the high yielding cow into the future. Rec. Adv. Anim. Nutr. Aust. 13:1-8.

Borman, J. M., K. L. Macmillan, and J. Fahey. 2004. The potential for extended lactations in Victorian dairying: A review. Aust. J. Exp. Agric. 44:507-519.

Buckley, F. K., J. F. O'Sullivan, J. F. Mee, R. D. Evans, and P. Dillon. 2003. Relationships among milk yield, body condition, cow weight, and reproduction in spring-calved Holstein-Friesians. J. Dairy Sci. 86:2308-2319.

Butler, W. R. 1998. Review: Effect of protein nutrition on ovarian function and uterine physiology in dairy cattle. J. Dairy Sci. 81:2533-2539.

Carrick, M. 2003. Crossbreeding dairy cattle. The Australian Dairy Farmer 107:18.

Dairy Australia. 2006. Situation and Outlook. http://www.dairy australia.com.au Accessed Sept. 1, 2006.

Dillon, P., S. Snijders, F. Buckley, B. Harris, P. O'Connor, and J. F. Mee. 2003. A comparison of different dairy breeds on a seasonal grass-based system of milk production 2 . Reproduction and survival. Livest. Prod. Sci. 83:35-42.

Earle, D. F. 1976. A guide to scoring dairy cow condition. J. Agric. $74: 228-231$.

Fulkerson, W. J., J. Wilkins, R. C. Dobos, G. M. Hough, M. E. Goddard, and T. Davison. 2001. Reproductive performance in Holstein-Friesian cows in relation to genetic merit and level of feeding when grazing pasture. Anim. Sci. 73:397-406.

GenStat 9.1. 2006. VSN Int., Hemel Hempstead, Hertfordshire, UK.

Grainger, C., G. D. Wilhelms, and A. A. McGowan. 1982. Effect of body condition at calving and level of feeding in early lactation on milk production of dairy cows. Aust. J. Exp. Agric. Anim. Husb. 22:9-17.

Hosmer, D. W., and S. Lemeshow. 2000. Applied Logistic Regression. 2nd ed. John Wiley \& Sons, New York, NY.

Livestock Improvement Corporation. 2003. Dairy Statistics. http:// www.lic.co.nz Accessed Sept. 1, 2006.

Lopez-Villalobos, N., D. J. Garrick, C. W. Holmes, H. T. Blair, and R. J. Spelman. 2000. Profitabilities of some mating systems for dairy herds in New Zealand. J. Dairy Sci. 83:144-153. 
Lucy, M. C. 2001. Reproductive loss in high producing dairy cattle: Where will it end? J. Dairy Sci. 84:1277-1293.

Macmillan, K. L., and J. D. Watson. 1975. Factors affecting A. B. conception rates. V. Cow age and stage of oestrus at insemination. N. Z. J. Exp. Agric. 3:29-35.

Morton, J. M. 1999. High genetic merit and high-producing dairy cows in commercial Australian herds don't have substantially worse reproductive performance. Br. Soc. Anim. Sci. Occ. Publ. No 26:305-311.

Pryce, J. E., and R. F. Veerkamp. 2001. The incorporation of fertility indices in genetic improvement programmes. Fertility in the high-producing dairy cow. Br. Soc. Anim. Sci. Occ. Publ. No. 26:237-249.
Roche, J. R., P. G. Dillon, C. R. Stockdale, L. H. Baumgard, and M. J. VanBaale. 2004. Relationships among international body condition scoring systems. J. Dairy Sci. 87:3076-3079.

Standing Committee on Agriculture. 1990. Feeding Standards for Australian Livestock: Ruminants. Commonwealth Scientific and Industrial Research Organization, E. Melbourne, Victoria, Australia.

Snijders, S. E. M., P. G. Dillon, K. J. O’Farrell, M. Diskin, A. R. G. Wylie, D. O'Callaghan, M. Rath, and M. P. Boland. 2001. Genetic merit for milk production and reproductive success in dairy cows. Anim. Reprod. Sci. 65:17-31.

White, T. L. 2001. Reproductive performance of Holstein-Friesian $\times$ Jersey crossbreds in predominantly Holstein herds. Honors thesis. The University of Melbourne, Australia. 